\section{ROYAL COLLEGE OF SURGEONS OF ENGLAND.}

Extraordinary CoUncil, May 4TH, 1898.

Sir Wilimam Mac Cormac, President, in the Chair.

THE minutes of the quarterly Council on April 14th were read and confirmed.

Admission of a Fellow.-Mr. C. S. Tomes, F.R.S., was admitted a Fellow of the College.

Practitioners in Italy. - A letter was read from the Secretary of State for Foreign Affairs, enclosing a copy of a despatch from Her Majesty's Ambassador at Rome reporting that the Italian Government do not contemplate making any change in existing laws with respect to the status of foreign practitioners in Italy.

Midwives Registration Bill.-The Council considered the report of the General Medical Council on the above, ${ }^{1}$ and adopted this report with the exception of Clause 6, and a verbal change in Clause 9, where they recommended the use of the word " nursing "in place of " after-care."

It was resolved that Mr. Rowland Humphreys be informed of the decision of the Council of the Royal College of Surgeons.

Corporation Duty.-A letter was read from Mr. Ernest J Wilde, the solicitor of the College, reporting that the claim of the College for exemption from Corporation Duty was heard on April 28th and 29th, before Mr. Justice Wright and Mr. Justice Channell, and that they gave judgment in favour of the Crown, except as regards the Conservator's House, which they considered to be exempt from duty, this partial success relieving the College from having to pay the costs of the Crown. The Council will consider the question of appeal at its meeting next week.

\section{ACADEMY NOTES.}

IT is impossible to deny that the Royal Academy has lately lost a little of its former hold on secial attention. This was specially noticeable last year when a commonplace collection of pictures, badly hung, co-operated with the loss of the two most prominent leaders of British art to make a dull impression on the public mind, and a considerable reduction in the annual receipts. We are therefore all the more happy to be able to congratulate the authorities of Burlington House on the more cheerful prospects of the coming season. Art seems to have resumed its old place as a leading conversational topic, and the verdict both of the general public and of those more authoritative persons who claim under the name of critics the right to guide our taste, is that the present show far excels in brilliancy and interest its immediate predecessors, and is well worthy of careful study; and we do not think that we shall offend national patriotism when we give some part of the credit of this revival to the two brilliant Americans who have placed their genius at our disposal. It has not.yet been found necessary to place a rail in front of Abbey's "King Lear," but the daily crowds who gather four and tive deep in front of this able and attractive work show that the public taste is generally tolerably sound, and that a really good thing in painting, as in everything else, will never lack appreciation; and Sargent's dexterous and sparkling portraits, dashed upon the canvas with superb audacity and almost palpitating with vigorous and characteristic life, show what can be done by the infusion of strong and enthusiastic personality into the occasionally too solid flesh of the ordinary sitter.

Herkomer is also in great force this year, and Orchardson reigns supreme in his two principal works. The old Scotch lady, with her combined look of patient and almost resigned dignity, contrasts sharply with her neighbour, the late Speaker, sitting "on the pounce," with the "Order, order!" face so familiar to members of the House of Commons, and by which we understand that he specially desired to be handed down to posterity. As long as works of this forcible yet simple power continue to be produced the British school may defy competition.

Yet wholesome rivalry from across the Channel is not wanting. Carolus Duran has sent from his Paris studio two beautiful specimens of his assured and skilful mastery over

\footnotetext{
1 Bee British Mgdical Jovralal, April 16th, p. 1037.
}

the difficulties of flesh tints and fashionable clothes, and Bonnat and Constant make good their claim to rank high in their respective lines.

Space does not allow us to go into any detailed examination of the "pictures of the year," but we should like to thank the Hanging Committee for the admirable way in which they have done their work. Not only is the general effect of the show excellent, but each individual item is placed where it can be seen to the best advantage, and amid surroundings which enhance rather than impair such qualities as it may possess.

It is therefore a real pleasure to go round the rooms to renew the acquaintance of old friends and be introduced to new, and coming out of the dust and bustle of London streets, it is refreshing to feel the spray of Peter Graham's matchless waves cooling the air, to sun ourselves beneath MacWhirter's blue skies, and to ramble with more or less poetic feeling through woods and over moors by the side of David Murray and Alfred East and Parsons.

Students of longevity cannot fail to note with satisfaction the undimmed eye and unfailing hand with which sidney Cooper, at the age of 95, continues to ply his brush in his much-loved Canterbury meadows, and how Watts and Hook show that the term of octogenarian is compatible with the full retention of the great powers which are the admiration of us all.

It is remarkable how completely matters medical have been ignored in our present Academy; not a single sick child or convalescent girl, or dying veteran appeals to the sentiment of the tender-hearted; and whilst mayors and J.P.'s in every variety of ceremonial costume beam blandly on us from every wall, only two doctors-Anderson Critchett and Pickering Pick-have been called upon to endure the combined ordeal of sitting and hanging. Finally, no member of our profession has contributed anything this year. Sir Henry Thompson has apparently forsaken for the astronomical laboratory the studio from which so many excellent works used to emerge ; and Sir Seymour Haden's sight nolonger enables him to practise the delightful art in which he formerly excelled.

But there is much artistic talent secluded behind brass plates in all parts of London, and we hope to see it coming into the open at some future time, and showing that the keen eye and sure hand of our professional brethren can turn itself to something even more interesting than handling the stethoscope and scalpel.

\section{THE PLAGUE IN THE EAST.}

Calcutta.-For the moment all interest in the plague is centred in the threatened outbreak in Calcutta. The actual records are, that, up to May ist, there had occurred in Calcutta 26 cases of plague and 12 deaths. The first assumption was that rats had brought the infection; this was based upon the fact that large numbers of dead rats had been found in the railway and steamship godowns (goods sheds). Since then opinion has veered round to the belief that the infection can be traced to a passenger from Bombay. It is well nigh an impossible task to trace the source of contagion with a frontier so wide as that of Bengal; but no doubt the most serious news is that rats are dying of plague in Calcutta. If the statement is true, there is every probability that plague will lay serious hold of the city. Patients with plague have been imported before and no spread resulted, but it is almost established as a principle that wherever rats die in numbers plague has come to stay. On May 2 nd, 2 fresh cases were reported and I death, that of a European. From Calcutta there has been an enormous exodus, estimated at 250,000 people. The bulk of those flying from the city are women and children-owing, it is believed, to the fear of segregation. Telegrams of May 3 rd state that the panic has subsided considerably and the exodus has abated, owing probably to the assurance given by the Lleutenant-Governor that the plague rules to be enforced would not be so stringent as those in Bombay. The same officer announced that, with the aid of the hot weather and the sanitary rules proposed, he had every reason to hope the disease would be stamped out quickly. Inoculation by Professor Haffkine's serum is being strongly recommended, and as an inducement to people to adopt the treatment the Gov 3 rnor has declared that, even 